\title{
EL DÍA MUNDIAL DE LA LÓGICA
}

\author{
Manuel Correia ${ }^{1}$ \\ Pontificia Universidad Católica de Chile
}

La UNESCO en su resolución del 17 de octubre de 2018, luego de haber considerado el reporte interno de la Comisión de Ciencias Sociales y Humanidades (SHS), adoptó para el 14 de enero de cada año el Día Mundial de la Lógica (World Logic Day). Es una fecha elegida por su significación ya que el día coincide con el nacimiento de Alfred Tarski (1901) y la muerte de Kurt Gödel (1978), dos lógicos señeros del siglo XX.

De este modo, la organización internacional hace otro gesto a la importancia de las humanidades en la educación de las nuevas generaciones y une esta fecha a la del 14 de noviembre, el Día Mundial de la Filosofía.

Como sabemos esta organización internacional tiene un mandato de promocionar la educación, la ciencia y la cultura, ${ }^{2}$ razón por la cual esta promulgación se aprecia coherente con su misión. Pero hay otros aspectos de este proceso de promulgación que me gustaría destacar.

En primer lugar, llama la atención el que se reconozca la lógica como un término unívoco, sin dificultades teóricas de fundación, aun cuando siempre ha oscilado entre ser un instrumento del saber y una ciencia. Esto significa que para la UNESCO la lógica no es un término ambiguo o una enseñanza donde algunas partes son más importantes que otras, o un solo instrumento o una ciencia en sí misma, sino que una disciplina que tiene un determinado objeto y una determinada actividad metodológica y que toda ella, se entienda de una manera u otra, merece un reconocimiento mundial por su aporte a la humanidad. Creo que en esta concepción de la disciplina tiene mucho que decir la perspectiva histórica que nos otorgó el renacimiento de la lógica a fines del siglo XIX y su vertiginoso desarrollo en el siglo XX.

Pero no es solo su nombre el que goza de aceptación mundial, según la UNESCO, sino también su saber. La Comisión ha aceptado que esta disciplina es un beneficio para el hombre individual y la comunidad, permitiendo que la lógica se identifique en gran medida con la razón humana. En los considerandos, el documento dice:

\footnotetext{
${ }^{1}$ E-mail: mcorreia@uc.cl

${ }^{2}$ La sigla UNESCO corresponde a United Nations Educational, Scientific and Cultural Organization. Esta organización especializada de las Naciones Unidas ha tenido una continua y variada actividad dentro de los principios que la rigen desde el año 1945 en que fue fundada. Ver también: https:// es.unesco.org/about-us/introducing-unesco
} 
Also recalling that logic, as a discipline that encourages rational and critical thinking, is of paramount importance for the development of human knowledge, science and technology.

La resolución también reconoce el aporte que la lógica hace a la paz y al diálogo así como al acuerdo y entendimiento entre las naciones. En este sentido, bastante más allá de los acostumbrados términos con los que sus propósitos y objetivos se describen, la lógica se presenta como una disciplina universal, desarrollada por diferentes culturas y no solo por la occidental. Bien por esta Resolución que además reconoce el aspecto dialéctico que está presente en la lógica cuando se ve a sí misma como una teoría de la argumentación:

Further recalling that the dissemination of logic, a discipline that was developed by different civilizations and is based on the virtues of discourse and argumentation, can contribute to the achievement of a culture of peace, dialogue and mutual understanding among nations.

De modo coherente, la UNESCO ha llamado a cultivar su estudio e investigación y a la vez hacer un esfuerzo por contribuir a su desarrollo dándola a conocer en los espacios públicos y promocionándola a través de la cooperación internacional. Este llamado es lo suficientemente amplio para no dejar fuera ninguna organización social y pareciera que la misma llamara a la responsabilidad de cada actor social en lo que respecta a su aplicación en nuestra vida diaria. Así, en su p. 5, se dice:

Convinced that the proclamation of world logic day would contribute to the development of logic, through teaching and research, as well as to public dissemination of the discipline and to the promotion of international cooperation in the field,

1. Invites the Member States of UNESCO to celebrate world logic day every year, organizing national events on 14 January with the active participation of governmental and non-governmental, public and private institutions concerned, such as schools, universities, research institutes, philosophical and scientific associations, and others,

2. Invites the Director-General to encourage and publicize initiatives taken in this regard at the national, regional and international levels, working closely with the International Council for Philosophy and Human Sciences (CIPSH),

3. Proclaims 14 January "World Logic Day", in association with the International Council for Philosophy and Human Sciences (CIPSH).

El 14 de enero de 2019 se celebró en Chile un encuentro en la Universidad de Valparaíso que permitió que Chile figurara dentro de los más de 60 lugares que 
estuvieron atentos y organizaron una reunión en honor a la lógica y a sus beneficios. Hay información detallada de al menos 33 países alrededor del mundo, ${ }^{3}$ donde los países en que mayor convocatoria hubo fueron Polonia, Brasil y Rusia. ${ }^{4}$

El sitio de Logica Universalis (http://logica-universalis.org/wld) presenta los siguiente cinco pasos para unirse a la segunda celebración del 14 de enero de 2020.

\section{EASY STEPS TO ORGANIZE A SUCCESSFUL WORLD LOGIC DAY IN A GIVEN LOCATION}

(1) Plan logical activities for January 14: a lecture, a workshop, an informal gathering, a logic tea party, a virtual event

(2) Build a webpage with this information, it will be linked below.

(3) Advertise and promote the event.

(4) Prepare the technical and practical details.

(5) Meet on location January 14, 2019.

El articulador y originador de esta idea es el lógico franco-suizo Jean-Yves Beziau, actualmente Presidente de la Academia Brasileira de Filosofía. En su breve comunicación informa del objetivo alcanzado y agradece a todos los académicos que organizaron una celebración o que apoyaron el proyecto. Al final de su mensaje se lee:

"Everybody is welcome to organize a celebration"

En el espíritu de esta conmemoración, que los que la hemos apoyado esperamos continúe y convoque cada vez más lugares en el mundo, se puede apreciar uno de los temas que vienen acompañando a la lógica desde sus primeros brotes modernos, a saber, la de convertirse en una suerte de lenguaje universal. No es propiamente una lengua, como el esperanto, sino un lenguaje expresivo de los contenidos verdaderos adquiridos por la ciencia. El lenguaje más expresivo de todos, aquel que puede expresar todo lo que se dice al interior de cualquier otra ciencia o práctica deductiva y que a su vez no es expresada completamente en ningún otro lenguaje. Tal vez la lógica se convierta en la lengua universal del conocimiento humano en el porvenir.

\footnotetext{
${ }^{3}$ Ver: http://www.logica-universalis.org/wld)

${ }^{4}$ Beziau, J.-Y. (2019), p. 1. Ver también: https://link.springer.com/article/10.1007/s11787-019-00221-5
} 


\section{BIBLIOGRAFÍA}

Beziau, J.-Y. (2019). “1 ${ }^{\text {st }}$ World logic Day: 14 January 2019”, Logica Universalis 13, pp. $1-20$. 